\title{
Quality of Health Services Before and During the Covid-19 Pandemic In Public Health Center
}

\author{
*Menap, Harmaen, Sastrawan \\ Master of Health Administration Study Program, Faculty of Health, Universitas Qamarul \\ Huda Badaruddin Bagu, Jl. H. Badaruddin Bagu 83562, Indonesia \\ *Corresponding Author e-mail: menap@uniqhba.ac.id
}

Received: July 2021; Revised: September 2021; Published: December 2021

\begin{abstract}
Performance evaluation of public health centers must be carried out to measure the level of achievement of quality performance based on customer perspectives and internal service processes. This study aims to evaluate the quality of outpatient services before and during the Covid-19 pandemic at the Aik Darek public health center, West Nusa Tenggara - Indonesia. This study is an exploratory research with comparative descriptive method. A total of 88 research samples were used based on files from outpatients who had visited before the Covid-19 pandemic (October to December 2019) and during the Covid-19 pandemic (March to May 2020). The instrument of this research is a questionnaire from 5 aspects of service quality, tangible, reliability, responsiveness, assurance, and empathy. Descriptive and statistical analyzes were conducted to compare service conditions based on established indicators. The results of this study clearly illustrate that the quality of service before the COVID-19 pandemic was better than during the Pandemic. Satisfaction on the tangible aspect is the most prominent compared to other aspects. The results of statistical analysis also showed significant differences in the two health care conditions based on the five aspects measured. Further description is presented in this article.
\end{abstract}

Keywords: Performance evaluation, health service, public health centers, Covid-19 pandemic

How to Cite: Menap, M., Harmaen, H., \& Sastrawan, S. (2021). Quality of Health Services Before and During the Covid-19 Pandemic In Public Health Center. Prisma Sains : Jurnal Pengkajian Ilmu dan Pembelajaran Matematika dan IPA IKIP Mataram, 9(2), 225-232. doi:https://doi.org/10.33394/j-ps.v9i2.4284

\section{INTRODUCTION}

The Sustainable Development Goals (SDGs) seek to ensure healthy and prosperous lives for all ages. The development of the health service system is expected to be able to improve quality towards achieving the Millennium Development Goals, many countries around the world are expanding the reach of service access by continuously improving the assessment of service standards. As a next step, the quality of health services must be integrated with the national development quality policy strategy of each country that reflects the ability to provide quality health services through a community-based service approach by encouraging active community involvement (Kruk et al., 2017).

In developing and poor countries, the quality of good health care and according to service standards is very important to continuously evaluate its effectiveness, especially with regard to aspects of the structure and process of the service. The quality of the service structure that most commonly affects the service process, such as: the availability of medicines, human resources, types of services, service standards, facilities and other supporting facilities must be ensured. Likewise, the quality of the service process as seen from the dimensions of satisfaction, perception and expectation is one of the indicators to improve the quality of services provided (Moucheraud \& McBride, 2020). 
Health care providers generally want their patients to be satisfied with their health problems. Satisfaction is an important element in measuring the quality of care, but to achieve an optimal level of patient satisfaction, service provider organizations need to improve their physical appearance, availability of equipment and service facilities and access to services through the availability of operational financing, standard procedures, diagnostic services, comfort, convenience. get services, and interpersonal communication between officers and patients. In general, patient satisfaction with service aspects includes tangible aspects, service reliability, responsiveness, assurance, and empathy (Umoke et al., 2020). Improving the quality of health services significantly has a relationship with the perceptions and expectations of service users, so that the service quality factor is an important factor that is closely related to patient satisfaction and perceptions as users of health services (Zaid et al., 2020). In addition, organizational culture also greatly influences the commitment of the publict health center organization to improve the quality of services provided to the public, especially with crisis situations such as the Covid-19 pandemic, which until now has not yet determined when it will end. Public health center as one of the public service organizations is expected to increase its commitment and responsibility to provide higher quality services and to minimize the gap between service needs and the quality of services provided (Hadian, 2017).

Based on this condition, health development in Indonesia is now beginning to be emphasized to improve the quality of its services, which are oriented towards achieving community satisfaction as service users. The quality of the service in question has been stated in the Regulation of the Ministry of Health of the Republic of Indonesia Number 43 of 2019, where the regulation mandates that every health service institution is obliged to carry out quality services through service quality control. During the Covid-19 pandemic, public health center as the spearhead of public health services at the sub-district level played an important role in clinical care, patient screening, and health promotion. In addition, coordination between service facilities, the community, the government, the provision of supporting infrastructure and the commitment of officers in providing quality services is very necessary, so that the weaknesses of the health service system (gaps) can be addressed appropriately and quickly (Lauriola et al., 2021).

Aik Darek Public Health Center as a technical implementing unit from the health office (Permendagri No 61, 2007) is given the flexibility to regulate its own financial management based on the principles of transparency, accountability, responsibility and independence effectively and efficiently, so that the implementation of operational activities takes place optimally in accordance with minimum service standards. Public health center. However, the impact of the Covid-19 pandemic has not yet been resolved, affecting the effectiveness of the financing of various operational activities that have been planned, such as efforts to maintain infrastructure, the provision of several health equipment and equipment as well as efforts to improve the quality of human resources at the Aik Darek Public Health Center. This condition is also exacerbated by limiting the number of visits, from an average of 25 to 30 people per day during the pre-pandemic period to 9 to 15 people per day during the COVID19 pandemic. This has a direct impact on the reduction in revenue from financing claims obtained by the public health center and has a direct impact on the effectiveness of the operational activities of the public health center.

Based on the analysis of conditions as described above, it is necessary to conduct a study related to the quality of health services at the public health center. This study aims to evaluate the quality of outpatient services before and during the Covid-19 pandemic at the Aik Darek Public Health Center, West Nusa Tenggara - Indonesia.

\section{METHOD}

The method used in this research is a comparative descriptive method with a quantitative approach. Comparative research is research that compares the existence of one 
variable or more different samples, or at different times (Esser \& Vliegenthart, 2017). Comparative research is expost facto, which is a systematic empirical research in which the researcher does not control the independent variable directly, because the independent variable has occurred in the past or because the independent variable basically cannot be manipulated (Creswell, 2017). The variable in this study is the quality of outpatient services, by comparing before and during the Covid-19 pandemic.

The population of this study was outpatients who had visited the Aik Darek Health Center before the Covid-19 pandemic from October to December 2019, and during the Covid-19 pandemic from March to May 2020. In these two conditions, 10 respondents were obtained each., where as many as 10 files per day multiplied by 72 days for a total of 720 files. The sample in this study is part of the population file taken as research subjects which is calculated using the Slovin's formula (Adam, 2020).

$\mathrm{n}=\frac{\mathrm{N}}{1+\mathrm{N} \cdot \mathrm{e} 2}$

Annotation:

$\mathrm{n}=$ sample size

$\mathrm{N}=$ population size

$\mathrm{e}=$ percentage of tolerance level of error in sampling $(\mathrm{e}=0.1)$

Thus, the sample size of this study is as follows.

$\mathrm{n}=\frac{720}{1+720 .(0.01)}$

$\mathrm{n}=87.80$ rounded up to 88 sample files

The instrument of this research is a questionnaire about 5 dimensions of service quality which consists of aspects of tangible, reliability, responsiveness, assurance, and empathy. The instrument was adopted from the service quality assessment instrument "SERVQUAL" (Zeithaml et al., 2017). The method of observing the quality of outpatient services is arranged with the following steps: editing, coding, entry, and cleaning (Moser \& Korstjens, 2018).

Descriptive and statistical data analysis with computerized assistance (Strata Version 16) consisting of: univariate analysis used to show the frequency distribution and percentage of variable characteristics, and bivariance used to analyze differences between service quality variables before and during the Covid-19 pandemic with statistical test independent sample ttest at confidence level $\alpha(0.05)$.

\section{RESULTS AND DISCUSSION}

The level of satisfaction with the quality of service at the Aik Darek Health Center before the Covid-19 pandemic varied on 5 dimensions of service quality. The range of data on the number of those who said they were satisfied ranged from $39.77 \%$ to $60.23 \%$. The level of satisfaction with the service quality is the lowest in the tangible dimension $(39.77 \%)$. The level of satisfaction with the quality of service at the Aik Darek Public Health Center before the Covid-19 pandemic is presented in Figure 1. 


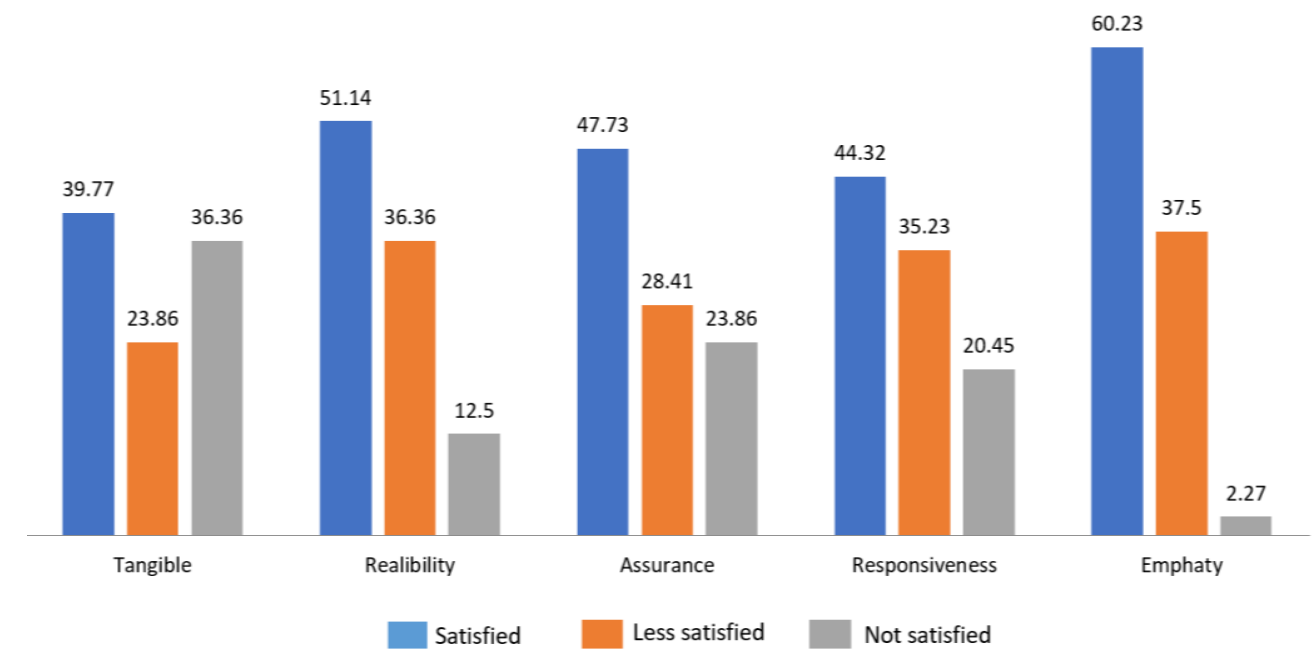

Figure 1. Frequency distribution of patient satisfaction levels at the Aik Darek Public Health Center before the Covid-19 pandemic

Tangible dimension shows the lowest level of satisfaction with service quality with two assessment elements consisting of: elements of comfort and cleanliness of the room, as well as elements of appearance and tidiness of officers. The element with the least average score is found in the appearance and neatness of the officers. The tangible dimension as a quality dimension relates to the real conditions of the service environment and the performance of officers, this is a very important indicator of service quality assessment. The respondent's low perception of the appearance and neatness of the officers (performance) positively affects the respondent's trust in the ability of the officer's performance.

Dissatisfaction with the service quality of the Aik Darek Public Health Center during the Covid-19 pandemic varied (see Figure 2). The level of satisfaction in each dimension of service quality can be seen from the percentage range of the number of respondents who stated that they were not satisfied between $39.77 \%$ to $51.14 \%$. The highest perception of respondents' dissatisfaction is found in the tangible dimension $(51.14 \%)$.

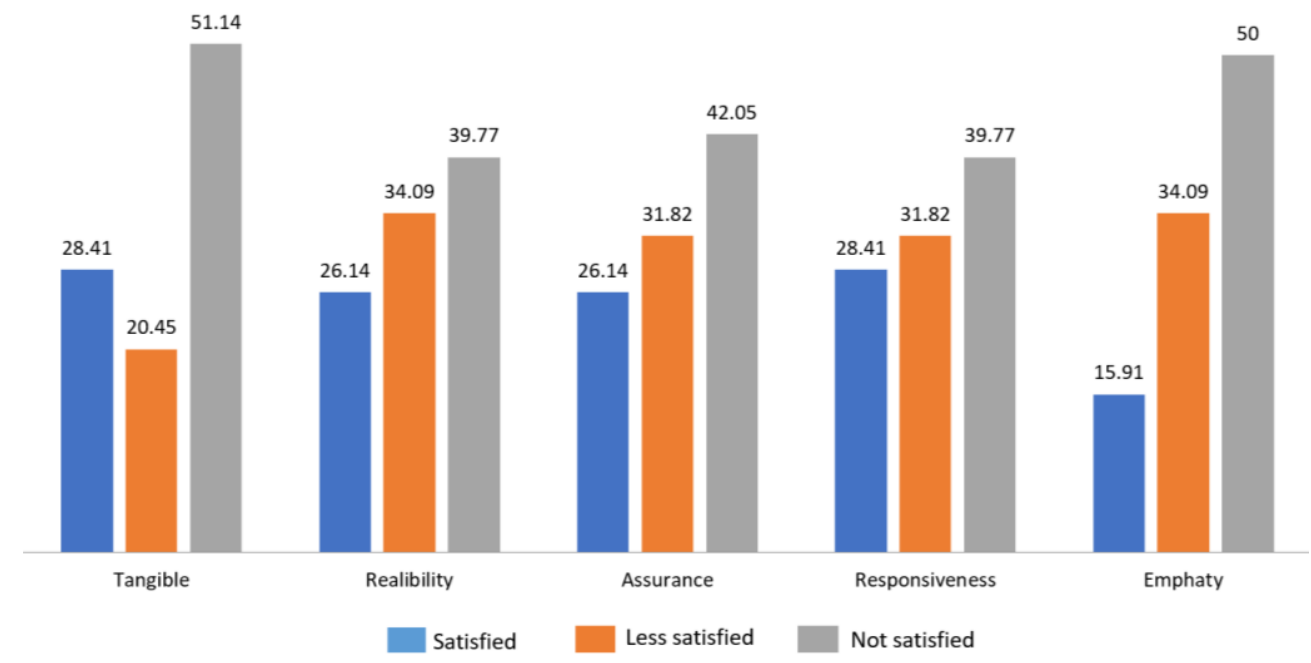

Figure 2. Frequency distribution of service quality based on the level of satisfaction at the Aik Darek Public Health Center during the Covid-19 pandemic

The elements of comfort and cleanliness of the waiting room are the elements that most influence the high number of respondents' dissatisfaction with the quality of service in terms of the tangible dimension. The comfort and cleanliness of the waiting room which is not good 
is one of the factors that affect the perception and expectations of respondents on the quality of service at the Aik Darek Health Center. Physical appearance, equipment, cleanliness, tidiness and comfort of services that do not meet quality standards are most likely due to the unpreparedness of service management to deal with the Covid-19 pandemic crisis, especially in the first 2 to 3 months of the pandemic.

Furthermore, to prove that there is a significant difference between the quality of service before the Covid-19 pandemic and the quality of service during the pandemic, a statistical test was carried out, with an independent sample t-test. From the results obtained, the difference between before the Covid-19 pandemic obtained a mean value of 46.11, and during the Covid-19 pandemic the mean value was 44.79 , indicating a positive difference of (diff 1.32). And this difference shows that the service quality variable before the Covid-19 pandemic was higher than the service quality variable during the Covid-19 pandemic.

The difference between the 5-dimensional variable of service quality before the Covid19 pandemic and the 5-dimensional variable of service quality during the Covid-19 pandemic showed that $\mathrm{p}(0.000)$ was smaller than alpha (0.05). These results illustrate that the null hypothesis (Ho) in this study cannot be accepted. So it can be concluded that there is a difference between the quality of service in the period before the Covid-19 pandemic and the quality of service during the Covid-19 pandemic as perceived by respondents in the 5 dimensions of service quality.

Table 1. The results of the analysis of differences in service quality before and during the Covid-19 pandemic

\begin{tabular}{lcccccccc}
\hline \multicolumn{1}{c}{ Variabel } & Abs. & Mean & Std.Err & Std.Dev & (95\% Conf. Int.) & df & t-score & $\mathrm{p}$ \\
\hline Before pandemic & 88 & 46.102 & 0.289 & 2.712 & $45.527-46.676$ & 87 & 4.301 & 0.000 \\
During pandemic & 88 & 44.784 & 0.340 & 3.196 & $44.106-45.461$ & & & \\
Diff. & 88 & 1.318 & 0.306 & 2.874 & $0.7090-1.9273$ & & & \\
\hline
\end{tabular}

The quality of service before the Covid-19 pandemic showed that of the 5 dimensions of service quality, the tangible dimension, namely the dimension that describes the physical appearance of the building and the public health center environment as well as the appearance of the officers, in the period before the Covid-19 pandemic the Tangible dimension showed the dimension with the best quality level achievement. satisfaction is low (39.77\%) with elements of appearance and tidiness of officers as the most dominant elements affecting the low quality of the tangible dimension, which is equal to (mean $=4.45)$. The quality of service perceived by patients about the ability of service providers to provide services based on physical appearance standards and the appearance of officers, shows a picture of the expected quality so as to be able to provide satisfaction and increase customer loyalty to continue to trust service providers as providers who can meet patient expectations (Parasuraman et al., 1975).

Based on the concept of service quality on the tangible dimension with elements of appearance and tidiness of officers as an indicator of service quality, this element is important to pay attention to. The use of uniforms that are equipped with personal identities as a form of depicting the professional image of officers can affect patient interactions with health workers during service delivery, and the low appearance and tidiness of officers can reduce the level of patient trust in officers. And the statement by (DH/CNO Directorate/Patient Environment Team, 2010) confirmed that the lack of good appearance and tidiness of the officers showed a picture of the unprofessional image of the officers and the lack of attention of the officers to their own image affected the perception of patient dissatisfaction about the professional quality standards of the officers. Therefore, the Aik Darek Public Health Center as a primary service provider that is directly in contact with the community has a responsibility to improve the quality of its services, especially those related to the appearance 
and tidiness of the officers. The need for uniforms used by officers should look clean, neat, complete with personal identity, which is expected to provide a feeling of satisfaction, security and comfort. Furthermore, (Wills et al., 2018) proves that the appearance and tidiness of the officers have influenced the patient's perception of the professional image of the officer and the patient's impression of the professionalism of the officer which depends on the appearance of the officer. A negative impression about the appearance of the officer can reduce the patient's trust in the officer and is directly correlated with the quality of service, so when the patient does not feel confident with the performance of the officer, it has an impact on patient dissatisfaction with the services available.

During the early period of the Covid-19 pandemic, the unpreparedness of health facilities, especially public health center in dealing with the impact of the Covid-19 pandemic infection, had an uncertain impact on service patterns that did not provide a sense of comfort and safety, not to mention the result of changing policies that confused all parties., it is shown in the results of this study, that the factor of comfort and cleanliness of the waiting room (mean=4.45) affects the quality of the physical appearance of the public health center, which is perceived to be patient dissatisfaction (51.14\%). The unprecedented impact of the Covid-19 pandemic puts heavy pressure on health service providers, especially on the strength of health service centers to continue to survive the impact of the Covid-19 pandemic, policies to prevent the spread of Covid-19 infections continue to be adjusted to the conditions of the development of the pandemic. Covid-19 to ensure the comfort and safety of patients, staff and the public (Tripathi \& Siddiqui, 2020).

The comfort and cleanliness of the waiting room as an indicator of service quality in the tangible dimension that affects the perceptions and expectations of respondents at the Aik Darek Health Center is important to be followed up. Because maintaining, improving and maintaining the comfort and cleanliness of the service environment is one of the main programs for the prevention and control of infectious diseases. The perception of the quality of the comfort of the service room environment, including the waiting room, is important to note, because health care facilities are quite complex buildings to accommodate various kinds of activities, so the comfort needs of officers and patients become one of the priorities to be implemented. Comfort and cleanliness include regulating indoor air quality, setting lighting systems, setting green open spaces and the availability of children's play areas are ways to reduce the spread of infection and can reduce patient boredom in the waiting room. During the Covid-19 pandemic, there are also procedures for limiting the number of visits, the availability of personal protective equipment for officers, setting check distances, the availability of hand washing stations, disinfection of waiting rooms, and the mandatory use of masks for patients and families, the use of transparent splash guards placed in the counter room area, examination rooms, drug rooms and laboratory rooms must be fulfilled to support the effectiveness of preventing the spread of Covid-19 infection, which is expected to increase satisfaction and increase patient confidence in health services (Eijkelenboom et al., 2021).

Differences in perceptions expressed in the form of differences in satisfaction levels are known to have a $\mathrm{p}$ value $(0.000)$ which is smaller than alpha $(0.05)$ in the independent sample t-test, which provides an overview of the significant difference between the quality of service before the Covid-19 pandemic and the quality of service in the past. the time of the Covid-19 pandemic. The difference in the average value between before the Covid-19 pandemic was also known to be (46.11) and during the Covid-19 pandemic it was (44.79), this shows a positive difference of (diff 1.32). This difference shows that the service quality variable before the Covid-19 pandemic was higher than the service quality variable during the Covid19 pandemic. This picture shows that there are similarities with the results of previous studies (Hadian, 2017) which states that the effect of the Covid-19 pandemic on the effectiveness of the health care system is influenced by the unpreparedness of health service management in overcoming the impact of the Covid-19 pandemic. 


\section{CONCLUSION}

The results of this study clearly illustrate that there are differences in service quality before the COVID-19 pandemic and during the Pandemic. The unique thing is that the quality of health services during the Pandemic was not better, meaning that there was a decline in services during the Covid-19 Pandemic. This is almost in all service indicators, ranging from tangible, reliability, responsiveness, assurance, and empathy. Descriptive and statistical analysis also shows differences in the quality of health services during the Covid19 pandemic. This result is a challenge as well as an improvement factor that must be addressed at the Aik Darek Health Center to continue to make improvements to provide the best service in the public health sector.

\section{RECOMMENDATION}

This study can be a reference for similar research and can be developed, both in aspects of methodology, theoretical concepts and instruments used in research. In terms of research results, of course, this becomes input for stakeholders to continue to evaluate and make improvements to the quality of health services at public health centers.

\section{ACKNOWLEDGMENT}

This study is an independent research conducted by lecturers in the context of fulfilling the university's tridharma duties. The researcher would like to thank the parties involved in this study.

\section{REFERENCES}

Adam, A. M. (2020). Sample Size Determination in Survey Research. Journal of Scientific Research and Reports, 26(5), 90-97. https://doi.org/10.9734/JSRR/2020/V26I530263

Creswell, J. W. (2017). Research Design Pendekatan Metode Kualitatif Kuantitatif dan Campuran (ed. 4th). Pustaka Pelajar.

DH/CNO Directorate/Patient Environment Team. (2010). Uniforms and workwear: Guidance on uniform and workwear policies for NHS employers. Departatment of Health, April, 16.

Eijkelenboom, A., Ortiz, M. A., \& Bluyssen, P. M. (2021). Preferences for indoor environmental and social comfort of outpatient staff during the COVID-19 pandemic, an explanatory study. International Journal of Environmental Research and Public Health, 18(14). https://doi.org/10.3390/ijerph18147353

Esser, F., \& Vliegenthart, R. (2017). Comparative Research Methods. The International Encyclopedia of Communication Research Methods, 1-22. https://doi.org/10.1002/9781118901731.IECRM0035

Internasional, T., \& Hadian, D. (2017). Hubungan Budaya Organisasi dan Komitmen Organisasi terhadap Kualitas Pelayanan Publik; Perspektif Pemerintah Daerah di Bandung, Indonesia. 7(1), 230-237.

Kruk, M. E., Kelley, E., Syed, S. B., Tarp, F., Addison, T., \& Akachi, Y. (2017). Measuring quality of health-care services: what is known and where are the gaps? Bulletin of the World Health Organization, 95(6), 389. https://doi.org/10.2471/BLT.17.195099

Lauriola, P., Martín-Olmedo, P., Leonardi, G. S., Bouland, C., Verheij, R., Dückers, M. L. A., Van Tongeren, M., Laghi, F., Van Den Hazel, P., Gokdemir, O., Segredo, E., Etzel, R. A., Abelsohn, A., Bianchi, F., Romizi, R., Miserotti, G., Romizi, F., Bortolotti, P., Vinci, E., ... Zeka, A. (2021). On the importance of primary and community healthcare in relation to global health and environmental threats: Lessons from the COVID-19 crisis. BMJ Global Health, 6(3), 1-7. https://doi.org/10.1136/bmjgh-2020004111

Moser, A., \& Korstjens, I. (2018). Series: Practical guidance to qualitative research. Part 3: Sampling, data collection and analysis. European Journal of General Practice, 24(1), 
9-18. https://doi.org/10.1080/13814788.2017.1375091

Moucheraud, C., \& McBride, K. (2020). Variability in health care quality measurement among studies using service provision assessment data from low-And middle-income countries: A systematic review. American Journal of Tropical Medicine and Hygiene, 103(3), 986-992. https://doi.org/10.4269/ajtmh.19-0644

Parasuraman, A., Valarie A., \& Zeithaml L. L. B. (1975). Regulation of the hut operons of Salmonella typhimurium and Klebsiella aerogenes by the heterologous hut repressors. Journal of Bacteriology, 124(3), 1269-1272. https://doi.org/10.1128/jb.124.3.12691272.1975.

Permendagri No 61, T. 2007. (2007). Permendagri No 61 Tahun 2007. 44(2), 8-10.

Tripathi, S. N., \& Siddiqui, M. H. (2020). Assessing the quality of healthcare services: A SERVQUAL approach. International Journal of Healthcare Management, 13(S1), 133-144. https://doi.org/10.1080/20479700.2018.1469212

Umoke, M., Umoke, P. C. I., Nwimo, I. O., Nwalieji, C. A., Onwe, R. N., Emmanuel Ifeanyi, N., \& Samson Olaoluwa, A. (2020). Patients' satisfaction with quality of care in general hospitals in Ebonyi State, Nigeria, using SERVQUAL theory. SAGE Open Medicine, 8, 205031212094512. https://doi.org/10.1177/2050312120945129

Wills, N. L., Wilson, B., Woodcock, E. B., Abraham, S. P., \& Gillum, D. R. (2018). Appearance of Nurses and Perceived Professionalism. International Journal of Studies in Nursing, 3(3), 30. https://doi.org/10.20849/ijsn.v3i3.466

Zaid, A. A., Arqawi, S., Al Shobaki, M. J., Arqawi, S. M., Mwais, R. M. A., \& Abu-Naser, S. S. (2020). The Impact of Total Quality Management and Perceived Service Quality on Patient Satisfaction and Behavior Intention in Palestinian Healthcare Organizations Deep Learning Applications View project Wearable Microstrip Ultra-Wideband Antenna used for Early B. 62(03), 221-232.

Zeithaml, V. A., Berry, L. L., \& Parasuraman, A. (2017). The Nature and Determinants of Customer Expectations of Service: Http://Dx.Doi.Org/10.1177/0092070393211001, 21(1), 1-12. https://doi.org/10.1177/0092070393211001 